\title{
AN EMPIRICAL STUDY ON PENSION FUNDS' PORTFOLIO AND INVESTMENT PERFORMANCE: THE EFFECT OF PENSION FUNDS' SIZE
}

\author{
Yulia Vidya Nanda ${ }^{1}$, Apriani Dorkas Rambu Atahau** \\ ${ }^{1}$ Graduates from Department of Accounting, Universitas Kristen Satya Wacana, Indonesia \\ ${ }^{2}$ Department of Management, Universitas Kristen Satya Wacana, Indonesia \\ *Corresponding author; Email: ${ }^{2232014169 @ s t u d e n t . u k s w . e d u ; ~}{ }^{2}$ apriani@ staff.uksw.edu
}

\begin{abstract}
This study sought to investigate whether larger pension funds exhibited better investment performance than smaller ones and differences in the selection of investment instruments between large and small pension funds. Our research sample were 13 pension funds the members of BKS Dapen-KI (Badan Kerja Sama Dana Pensiun Kristen Indonesia - the Cooperation Council of Christian Pension Fund in Indonesia) in 2010-2017. It used the quantitatively descriptive and independent-sample $t$-test methods. The results indicated no significant difference between the performance of large and small pension funds likely because both pension fund types had relatively similar total assets. However, large and small pension funds had exhibit different investment instruments selection.
\end{abstract}

Keywords: Pension fund size, return on investment, investment instruments.

\section{Introduction}

The Indonesian population exhibits increasing awareness of the importance of old-age planning in line with a huge transition from a communal agrarian society to a more individualistic industrial society. Individuals cannot work in their whole life because of age limit in their life cycle that leads to declining physical ability and, eventually, productivity. Consequently, employers need to offer old-age allowances in the form of partial payments to their employees. These old-age allowances are commonly known as pension programs.

From the perspective of the national economy, pension funds are crucial for economic development and growth. For example, Davis and Hu (2005) reveal that the ratio between pension assets to Gross Domestic Products (GDP) has a significantly positive impact on per capita outputs in thirty-eight countries (twenty of them are developing ones). Due to its crucial role, governments strictly regulate the pension fund industry. According to Srinivas, Whitehouse, and Yermo (2000), governments' policies largely focus on three aspects, namely performance, industry structure, and asset allocation /investments. Government regulations strictly regulate the quantitative and qualitative limitations of pension funds' investments that are closely associated with performance that potentially offer guaranteed benefits to pension fund members.

The Law of the Republic of Indonesia Number 11 of 1992 (Undang-Undang No. 11 Tahun 1992) defines a pension fund as a program that promises a certain amount of money through periodic payments concerning the certain achievement of certain ages. Members are entitled to obtain pension benefits that are based on pension funds and pension fund types. There are two types of pension funds, namely employer's pension fund (DPPK - Dana Pensiun Pemberi Kerja) and financial institution pension fund (DP LK - Dana Pensiun Lembaga Keuangan). Banks and insurance companies exhibit similar characteristics in responsibilities on investment risks (participants bear the risks and firms or founders only determine the amount of contributions). However, the founders of employer pension funds bear the investment risks in the sense that they guarantee fund sufficiency.

DPPKs can offer defined benefit pension programs (PPMP - Program Pensiun Manfaat Pasti) or defined contribution pension programs (PPIP - Program Pensiun Iuran Pasti). In contrast, DPLKs can only offer defined contribution pension programs. The Indonesian Financial Services Authority (OJK - Otoritas Jasa Keuangan) classifies pension funds into four groups. Group I consists of pension funds with net assets equal to or above 1 trillion Rupiah. Group II includes pension funds with net assets equal to or above 500 billion Rupiah and less than 1 trillion Rupiah. Pension funds with net assets equal to or above 100 billion Rupiah and less than 500 billion Rupiah belong to Group III. Lastly, Group IV consists of pension funds with net assets less than 100 billion Rupiah. 
Data from OJK shows the decreasing trend of the number of pension funds (Otoritas Jasa Keuangan, 2016b) because of the dissolution of several pension funds (eight DPPK-PPMP and three DPPK-PPIP) and the conversion of two DPPK from PPMP to PPIP. The dissolution is likely because the founders of the pension funds dissolved, engaged in merger and consolidation activities, aimed for efficiency, or experienced financial difficulties. Also, founders are likely unable to maintain their financing levels.

The number of employer pension funds (DPPK) with defined benefit pension programs declined more than the number of employer pension funds with defined contribution pension program and financial institution pension funds of DPLK. An indicator for DPPKs to offer PPMP is their ability to finance their liabilities. The funding level is measured by comparing the amount of net assets with solvable liabilities and the present value of actuarial liabilities. The main component of pension funds to maintain their funding levels is investments because most pension funds' assets are allocated into investment (Satiti, 2013). Consequently, pension funds need to invest in growing their assets by managing contributions of their members, and it is crucial to evaluate the investment performance of pension funds to ensure whether pension funds have achieved their targeted performance. Performance evaluation in pension fund provides many benefits for the development and sustainability of pension fund like other institutions such as corporation and banks (Robiyanto, 2017).

Most of the study focus on pension fund performance (Jackwerth \& Slavutskaya, 2016; Bernardi \& Granzotto, 2018). In terms of efficiency, Sathye (2011) analyzes the technical efficiency of Australian retail pension funds by using operating costs and contribution value as the input variables and annual net assets value and pension benefit value as the output variables. The results indicate that Australian pension funds' efficiency is low, but their efficiency is correlated with pension funds' size. In a similar vein, Galagedera and Watson (2015) find that $11 \%$ of 173 pension funds exhibit highefficiency scores with retail pension funds as the most efficient group. Also, pension funds' assets are positively associated with performance. Measuring pension funds' performance needs to analyze their funding to understand the selection of appropriate investment instruments better. Thus, analyzing pension funds' size is very important.

Several studies analyze firms' size. For example, Haryanto (2016) reveals that size indicates to banks' total assets, average total sales, total sales, and average assets, and also size represents firms' ability, experience and risk level in managing their investments to maximize investors' wealth. Similarly, Atahau and Cronje (2014) demonstrate that size likely affects banks' portfolio return levels. Besides, Hendrawan and Lestari (2016) observe that larger banks are more likely to generate profits. However, prior studies focus on firms or banks and tend to overlook pension funds. Thus, this study analyzes pension funds' size.

This study focuses on pension funds that are the members of BKS Dapen-KI (Badan Kerja Sama Dana Pensiun Kristen Indonesia - the Cooperation Council of Christian Pension Fund in Indonesia) that mostly are DPPK PPMP. While the number of DPPK PPMP continued to decline, it is interesting to investigate the portfolio and investment performance evaluation based on pension funds' size of BKS Dapen-KI member pension funds. This study seeks to analyze pension funds' portfolio and performance based on pension funds' size. This study potentially informs OJK as the regulator to formulate policies concerning pension funds' investments and the members of BKS Dapen-KI to evaluate their investment performance. Besides, this study contributes to the literature on portfolio and investment performance based on pension funds' size.

Haryanto (2016) suggests that firm size represents banks' total assets, average total sales, total sales, and average assets. Banks' size likely affects their returns. Atahau and Cronje (2014) demonstrate that size affects portfolio returns because larger banks are better able to diversify their products. Larger firms are also more mature than small ones. Consequently, they have better long-term prospects and are better able to generate profits than smaller firms (Pangemanan \& Mawikere, 2011).

Pension funds with larger investments indicate that they have larger assets. Meanwhile, ROI indicates pension funds' performance because higher ROI represents a higher ability to diversify to generate economic profits. Haryanto (2016) shows that firms' size positively affects banks' capital. Besides, Hendrawan and Lestari (2016) reveal size affects banks' profitability, and consequently, larger banks generate higher profits. Meanwhile, Lipunga (2014) observes that banks' size affects their ability to bear probable risks. In the pension fund context, it is predicted that pension funds' size affects their ability to diversify investments and, eventually, their investment returns.

$H_{l}$ : Large and small pension funds exhibit different investment.

$\mathrm{H}_{2}$ : Large and small pension funds exhibit different investment returns. 


\section{Research Method}

\section{Research Sample and Data}

This study used the quantitative descriptive approach that collects, presents, and analyzes data to provide an understanding of the objects. The secondary data of the 2012-2012 financial statements was manually collected.

Our research population was pension funds that are the members of BKS Dapen-KI (Badan Kerja Sama Dana Pensiun Kristen Indonesia - the Cooperation Council of Christian Pension Fund in Indonesia) in the 2010-2017 period. The sample selection relied on the following criteria.

1. Pension funds that published annual financial statements for the 2010-2017 period.
2. Pension funds with complete ROI-related data.

3. Pension funds with complete total assets-related data.

4. Pension funds that did not incur losses/ discontinue the membership of BKS Dapen-KI in 2010-2017.

The sample selection criteria produced 13 pension funds out of a total of 15 members pension funds of BKS Dapen-KI and 104 total observations from the 2010 2017 period.

\section{Results and Discussion}

\section{Descriptive Statistics}

The following table summarizes the descriptive statistics of the member pension funds of BKS DapenKI. Table 1 shows that the large pension funds' three largest investment instruments were bonds, time

Table 1

Descriptive Statistics

\begin{tabular}{lrrrr}
\hline \multirow{2}{*}{ Investment Instrument } & \multicolumn{2}{c}{ Large Pension Funds } & \multicolumn{2}{c}{ Small Pension Funds } \\
\cline { 2 - 5 } & Mean (\%) & Std. Dev. & Mean (\%) & Std. Dev. \\
Government securities (GS) & 7.78 & 6.56 & 5.97 & 5.14 \\
Saving accounts (SA) & 1.35 & 2.05 & 0.58 & 1.13 \\
Time deposits TD) & 29.38 & 19.08 & 43.08 & 18.69 \\
Shares (Sh) & 6.78 & 7.03 & 10.07 & 10.56 \\
Bonds (Bo) & 36.82 & 15.49 & 20.08 & 11.90 \\
Money market, fixed income, share, and & 14.08 & 8.13 & 12.10 & 10.09 \\
combined mutual funds (MM) & & & & \\
Direct placement in shares (DP) & 0.73 & 1.01 & 1.31 & 1.99 \\
Land and buildings & 2.10 & 2.31 & 1.86 & 3.85 \\
\hline
\end{tabular}

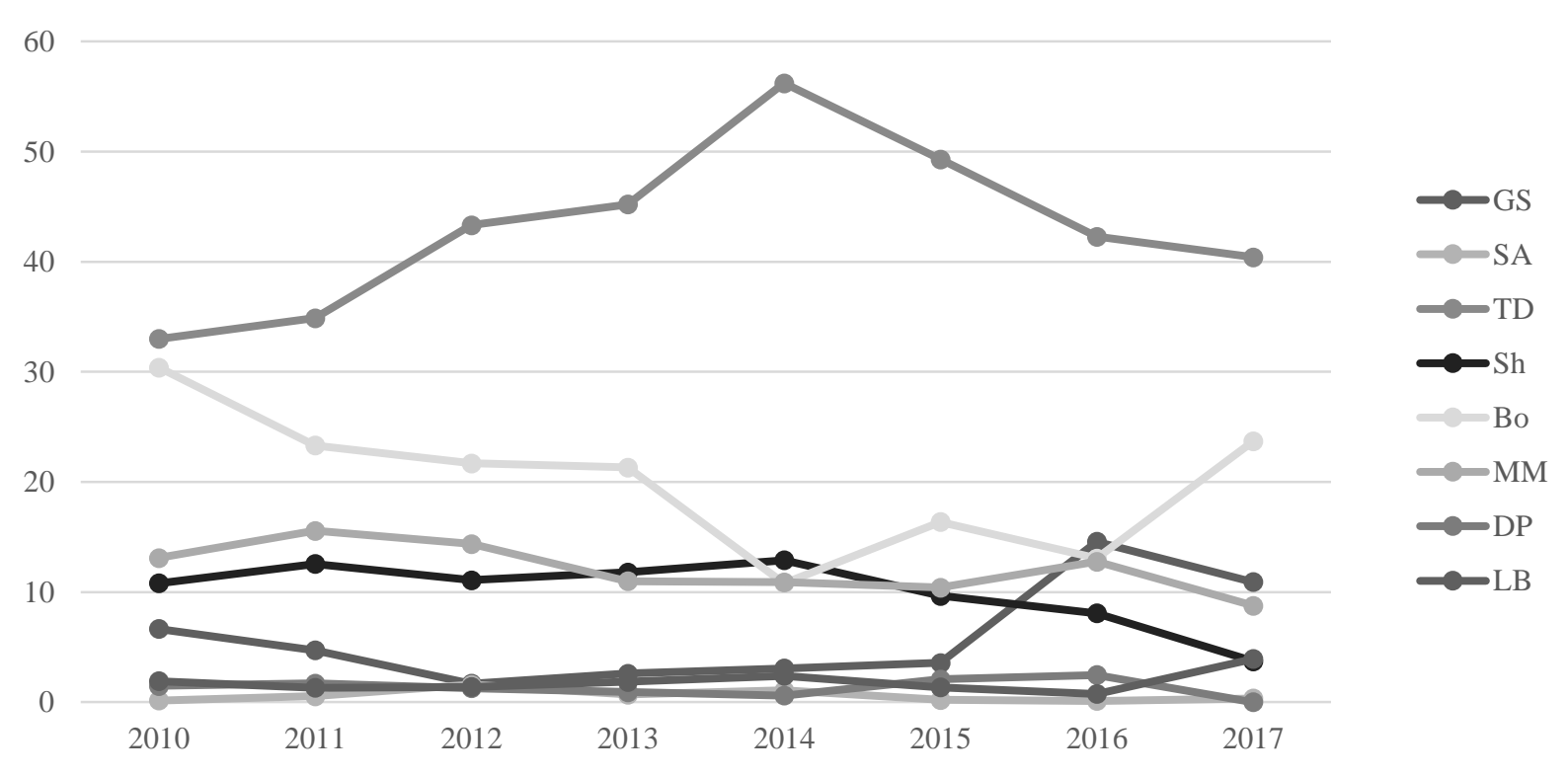

Figure 1. Investment portfolio of small pension funds (in percentage) 
deposits, and money market mutual funds. Meanwhile, the small pension funds' three largest investment instruments were time deposits, bonds, and money market mutual funds.

Table 1 also informs that the average percentage of the bond investment portfolio of large pension funds $(36.82 \%)$ was higher than that of small pension funds $(20.08 \%)$. Further, the average time deposit investment of small pension funds (43.08\%) was higher than that of large pension funds $(29.38 \%)$. The mean and standard deviation of bond and time deposit investment suggest that small pension funds focused more on time deposit investment than large pension funds. Conversely, small pension funds exhibit a higher percentage of share investment (10.07\%) than large pension funds $(6.78 \%)$.

Further, as indicated by Figure 1, the time-series data during the observation period (2010-2017) suggests that small pension funds mostly invested in time deposits. The proportion of investment in deposits had an increasing trend in 2010-2014 but a decreasing trend in the next period (2015-2017). Next, the second most investment instrument of small pension funds was bonds. Although bonds had a decreasing trend in the 2010-2015 period, they increased quite significantly in the $2016(28.95 \%)$, before it decreased again in year 2017.

Money market, fixed income, share, and combined mutual funds were the third-highest investment instrument of small pension funds. The graphic shows that in the first two years, the proportion of mutual funds increased and declined from 2012 to 2015 and 2017, but in 2016 it increased by $10.15 \%$. Further, the fourth most investment instrument of small pension funds was shares. In 2010 and 2011, the proportion of shares increased by $7.58 \%$, but in 2012 it decreased by $6.26 \%$, increased in 2013 and 2014, and starting from 2015 declined significantly (36.89\%). The fifth most investment instrument of small pension funds was government securities. The proportion of government securities to total investment instruments continued to decline from 2010 to 2012. However, from 2013 to 2016, it had the second-highest growth, with a significant increase of $60.61 \%$ likely because of the issuance of OJK Regulation No. 1/POJK. 05/2016 article 3a that required employer pension funds to invest in government securities at least $20 \%$ of their total investments (Otoritas Jasa Keuangan, 2016a). Lastly, land and buildings, direct placements in shares, and saving accounts were the least three investment instruments of small pension funds.

Figure 2 suggests that large pension funds invested mostly in bonds that increased by $8.401 \%$ in $2012-2013$ but declined until 2017. The second most investment instrument was time deposits that increased by $17.983 \%$ from 2010 to 2011 . These figures indicate that because large pension funds had large funds, they referred bond investment that had higher face value.

The money market, fixed income, share, and combined mutual funds were the third most investment instrument. The graphic informs that the proportion increased in all years except in 2013-2014 and 2016. Government securities ranked next. The proportion increased from 2010-2012, then declined in 2013-2015, and increased significantly $(64.31 \%)$ in the following year. Shares were the fifth investment instrument with a high increase in 2012 (31.06\%) but declined significantly in 2013 (21.91\%). Lands and buildings, saving accounts, and direct placements in shares were the least three investment instruments of large pension funds.

\section{Pension Funds' Investment Performance: The Effect of Pension Funds' Size}

The independent $t$-test was run to study the difference in the investment performance of large and small pension funds. The Table 2 displays the results.

The independent $t$-test produced the significance value (2-tailed) of $0.564>\alpha=5 \%$. The results suggest that large and small pension funds did not exhibit different investment performance likely because the total assets of both pension fund groups did not differ so much. In particular, their total assets were between 100 billion Rupiah and 200 billion Rupiah, and both groups had relatively similar total asset composition. The statistical data confirms our argument by showing that most of 13 members of BKS DAPEN-KI belonged to group IV with very low net assets.

\section{Discussions}

Small pension funds understandably focused on investing more in deposits because they had limited funding capabilities. Consequently, they tended to select conventional investment instruments, such as time deposits. Conversely, large pension funds invested more in bonds because they had more funds than small pension funds.

Besides, small pension funds exhibited a decreasing proportion of investment in deposits but an increasing percentage of investment in bonds and government securities in the 2016-2017 period likely because of OJK Regulation No 1/POJK.05/2016 concerning government securities investment by non-bank 
60

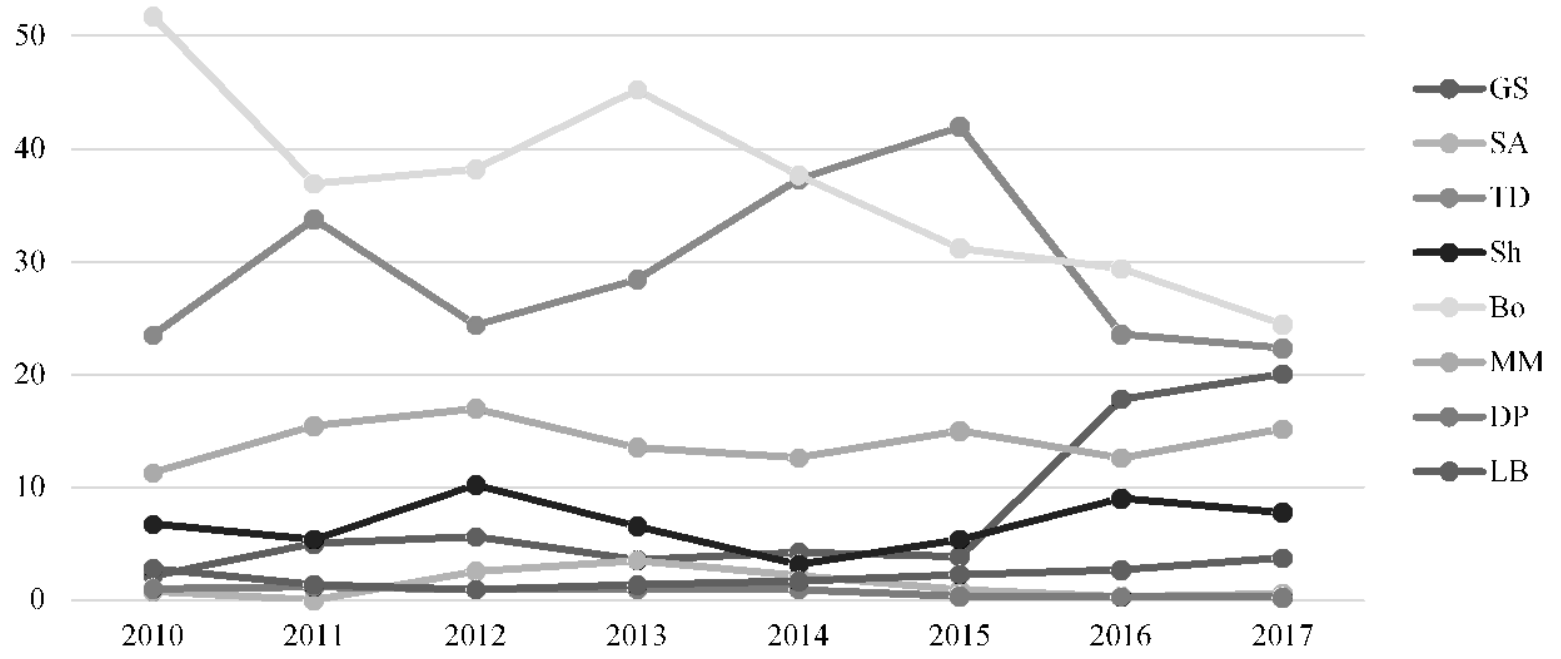

Figure 2. Investment portfolio of large pension funds (in percentage)

Table 2

Independent $t$-Test Result

\begin{tabular}{ccccccc}
\hline Variable & \multicolumn{3}{c}{ Small Pension Fund } & \multicolumn{3}{c}{ Large Pension Fund } \\
\hline \multirow{2}{*}{ ROI } & Mean & St. Dev & St. Error Mean & Mean & St. Dev & St. Error Mean \\
\cline { 2 - 7 } & 9.4315 & 3.83525 & 0.53185 & 8.9431 & 4.72841 & 0.65571 \\
\hline Sig. (2-tailed) & \multicolumn{5}{c}{0.564} \\
\hline
\end{tabular}

financial institutions. The regulation stipulated employer pension funds to invest in government securities or bonds at least 30\% from their total investments (Otoritas Jasa Keuangan, 2016a).

In a similar vein, the proportion of government securities investment also increased significantly in large pension funds (64.31\% in 2016), also likely because of the issuance of OJK Regulation No 1/POJK.05/ 2016. This regulation required increased investment in government securities instruments to support infrastructure development in Indonesia (Otoritas Jasa Keuangan, 2016a). This regulation is also in line with the public interest theory of regulation that argues that governments' regulations are a method to achieve efficiency (Arrow, 1969; Hertog, 2000; Shubik, 1970; Wood, 2006). Besides, this regulation more limited discretion for small pension funds to increase their investment returns because the returns of government securities were lower than the interest rates of rural banks (BPR Bank Perkreditan Rakyat).

Different pension funds' size that leads to different investment portfolio eventually results in different average performance. Large pension funds had a lower average ROI (8.94\%) than small pension funds $(9.4 \%)$ during the observation period. However, the $t$-test on the average performance of large and small pension funds did not produce a significant difference likely because the total assets of both pension fund groups in BKS Dapen-KI did not differ significantly. In particular, their total assets were between 100 billion Rupiah and 200 billion Rupiah. Consequently, their total asset compositions were relatively similar. The statistical data confirms our argument by showing that most of 13 members of BKS DAPEN-KI belonged to group IV with very low net assets.

\section{Conclusions and Implications}

This study aims to analyze whether large and small pension funds selected investment instruments differently and to investigate whether large pension funds had better investment performance (return on investment or ROI) than small pension funds. Our results conclude that large and small pension funds did not exhibit different ROI likely for the following reasons. First, the total assets of large and small pension funds in BKS Dapen- 
KI did not differ so much. Second, consequently, they had relatively similar total asset composition.

However, large and small pension funds had different investment instrument selection. The two investment instruments with the largest proportion investment of large pension funds were bonds and deposits. Conversely, small pension funds invested most in deposits and bonds. The difference was understandable because small pension funds only had limited funding that motivated them to select conventional instrument instruments such as deposits. However, large pension funds had greater funding that they were likely to select investment instruments that offered higher returns, such as bonds. Besides, both large and small pension funds still relied on fixed-income instruments that were heavily affected by the country-wide interest rates. Also, the issuance of the OJK regulation that stipulated the investment in government securities significantly affected the selection of investment instruments in both small and large pension funds.

Theoretically, our study adds the literature on the effect of pension funds' size on investment instrument selection. Practically, this research implies that the Financial Service Authority as pension fund regulator may consider the effect of mandatory regulation on pension fund performance since directing investment to government securities may reduce the pension fund returns. Managerial implications of this research are the need of pension funds to consider their investment instruments and diversify their investments to mitigate the impact of interest rate changes on portfolio performance. However, they need to make decisions more carefully by considering the expected risks and returns. In the future, regulators can take pension funds' size into account when making policies because large and small pension funds potentially adjust their portfolio differently as a response to these policies.

The range of total assets of small and large member pension funds of BKS Dapen-KI was relatively small (they belonged to groups III and IV based on total assets). Consequently, both pension funds had relatively similar total asset composition. For future research, include much more significant differences in total asset composition, such as those belong to group I and IV to analyze pension funds. Besides, future studies can focus on comparing the performance of small and large pension funds before and after the implementation of OJK regulation No. 1/POJK.05/2016 to offer a better understanding of pension fund groups that are most affected by the OJK investment regulations (Otoritas Jasa Keuangan, 2016a). It is advised for future research to use different measures of performance, such as operational costs, demography, and other factors.

\section{References}

Arrow, K. J. (1969). The organization of economic activity: Issues pertinent to the choice of market versus non-market allocation. Retrieved from https://msuweb.montclair.edu/ lebelp/arrownonmktactivity1969.pdf

Atahau, A. D. R., \& Cronje, T. (2014). Loan portfolio structure and performance of government-owned banks in Indonesia: Does size matter? Corporate Ownership \& Control, 11(4), 379-390

Bernardi, I., \& Granzotto, A. (2018). Are pension funds good monitors? RAUSP Management Journal, 53(2), 190-201. https://doi.org/10.1016/j.rauspm. 2017.06.003

Davis, E. P., \& Hu, Y.-W. (2005). Is there a link between pension-fund assets and economic growth? A cross-country study. Retrieved from http://citeseerx.ist.psu.edu/viewdoc/download? doi=10.1.1. 509.330\&rep=rep1\&type $=$ pdf

Galagedera, D. U. A., \& Watson, J. (2015). Benchmarking superannuation funds based on relative performance. Applied Economics, 47(28), 2959-2973.

Haryanto, S. (2016). Determinan permodalan bank melalui profitabilitas, risiko, ukuran perusahaan, efisiensi dan struktur aktiva. Jurnal Ekonomi Dan Bisnis, 19(1), 117-138

Hendrawan, Y., \& Lestari. (2016). Faktor-faktor penentu profitabilitas bank umum yang terdaftar di bursa efek Indonesia. Jurnal Manajemen dan Pemasaran Jasa, 9(1), 99-118

Hertog, J. D. (2000). General theoris of regulation. In B. Bouckaert \& G. De Geest (Eds.), Encyclopedia of law and economics Vol. 3 the regulation of contracts (pp. 223-270). Celtenham, UK: Edward Elgar Pub.

Jackwerth, J. C., \& Slavutskaya, A. (2016). The total benefit of alternatif assets to pension fund portfolios. Journal of Financial Markets, 31, 25-42. https:// doi.org/10.1016/j.finmar.2016.06.002

Lipunga, A. (2014). Determinants of profitability of listed commercial banks in developing countries: Evidence from Malawi. Research Journal of Finance and Accounting, 5(6), 41-49

Otoritas Jasa Keuangan. (2016a). Investasi surat berharga negara bagi lembaga jasa keuangan nonbank Peraturan OJK No. 1/POJK. 05/2016. Retrieved from https://ojk. go.id.

Otoritas Jasa Keuangan. (2016b). Statistik dana pensiun. Retrieved from https:// ojk.go.id.

Pangemanan, S., \& Mawikere, L. (2011). Pengaruh ukuran perusahaan dan pertumbuhan perusahaan 
terhadap earning per share pada industri tekstil di Bursa Efek Indonesia. Jurnal Riset Akuntansi dan Auditing Goodwill, 2 (1), 81-96.

Robiyanto, R. (2017). Performance evaluation and risk aversion rate for several stock indices in Indonesia Stock Exchange. Jurnal Manajemen dan Kewirausahaan, 19(1), 60-64.

Sathye, M. (2011). The impact of financial crisis on the efficiency of superannuation funds: Evidence from Australia. Journal of Law and Financial Management, 10(2), 16-27.

Satiti, N. R. (2013). Optimalisasi portofolio investasi dana pensiun Universitas Muhammadiyah Malang. Jurnal Manajemen Bisnis, 3(1), 73-84.
Shubik, M. (1970). On different methods for allocating resources. Kyklos, 13, 332-338. doi:https://doi.org/ 10.1111/j.146 7-6435.1970.tb02562.x

Srinivas, P. S., Whitehouse, E., \& Yermo, J. (2000). Regulating private pension funds' structure, performance and investments: Cross-country evidence. Discussion Paper. Social Protection Discussion Paper Series. The World Bank. Washington. Retrieved from http://www.worldbank.org/sp.

Undang-Undang Republik Indonesia No. 11 Tahun 1992 Tentang Dana Pensiun.

Wood, G. (2006). Governance or regulation? Efficiency, stability, and integrity in the financial sector. Journal of Banking Regulation, 7(1/2), 2-16. 